\title{
THE BASIC RESEARCHES OF MANETOL (No. 1)
}

\author{
By \\ T. SHIROIWA and a few others \\ Professor of the Ear, Nose \& Throat Section \\ Tokyo Medical College
}

Manetol is a kind of hemostyptica which the Bayer Co. in Germany has been successful in extracting from the spinal cord of animals. It has already been made clear that the main ingredient of Manetol is Organ-Thromboplastin, but its effective ingredient as well as its proper quantity to prove effective for a man has not yet been brought before the public.

So we have made some basic researches in regard to the said point which are considered to be necessary for any clinical operations. The essential point of our researches has been based on a standard of clotting effect that Manetol has, and the followings are the summarizations.

(1) Manetol urges blood clotting in case of being used both by means of intravenous injection and of direct effeet upon blood plasma. In these circumstances, Manetol should, to make it most effective, be diluted to some extent. By our researches the most effective standard of consistency of the said fluid is, experimentally, from $10 \%$ to $20 \%$ or thereabouts. The dilution of this kind proves most effective to cause blood clotting.

(2) In case of being used with a rabbit through an intravenous injection, $0.2 \mathrm{cc}$ of the said fluid is the proper quantity to urge blood clotting most effectively.

(3) Inferring from the proper quantity of injection against a rabbit, an injection of 6 or $7 \mathrm{cc}$ may be considered to be most effective for a man of full age to cause clotting.

(4) If Manetol is to be injected before any surgical operations, blood seems hard to run out of a cut incised for an operation. The reason of this fact may be considered that besides Thromboplastin of Manetol, tissue Thromboplastinogen contained in the tissue fluid of the cut, is usually activated by an operation making the tissue fluid urge blood to clot, still more Manetol in blood plays a greater part of helping this tendency.

(5) On analysing Manetol fluid, through paper chromatography, into some ten kinds of amino acid, considered as main constituent of the said fluid there to be found two or three kinds of them working more actively toward clotting than the others. In case we have an opportunity to obtain pure amino acid, the conclusion will be brought out more in detail.

(6) As a result of our various experiments of Manetol both on men and on animals, the side effect has not been acknowledged at all. 


\section{Manetol に関する基礎的研究（第 1 報）}

\begin{tabular}{|c|c|c|c|c|c|c|c|c|c|c|}
\hline 白 & 岩 & 俊 & 雄 & 宝 & 迫 & 慎一䬦 & $\prod_{x}$ & 村 & $\vec{x}$ & 枝 \\
\hline 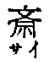 & 藤 & 光 & 慧 & $\underset{s}{\text { 田 }}$ & 村 & 伝 & 高 & $\begin{array}{l}\text { 橋 } \\
\Delta \Delta^{\prime}\end{array}$ & 晃 & \\
\hline
\end{tabular}

緒言

耳奥咽喉科領域の出血は，その殆てどが実貿性出血で あるため，手術中，術後あるいは外来処置時に出血に遭 遇すると，外科的の止血法は講じられない，我々耳鼻科 医は，この意味で常にその止血方法に悩ささ礼ている。 このために耳鼻咽脆科領域に和ける止血処置㮩は，止血 削が重要な役割を演ずる事は，周知の通りである．最近 我々は，奻弱屠殺獣の脊䯣より特殊な万法で抽出された Bayer の Manetol を有效な止血戍として, 日常の臨床 でいらも使用しているが，Manetol の構成々分及び有 初成分に関する研究報告は甚た簡略で，製法も，組成も

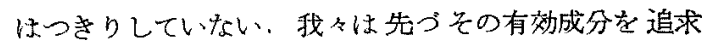
し，人に刘してどの位の投与量が最も止仰の効果が強い のかたどの点について臨床上最も知りたい不明な部分を 基礎的研究して見た。

\section{研究 項 目}

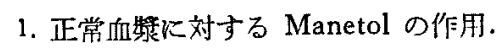

2. 正常血獎に対する Manetol の濃度による作用の変 動.

3. Manetol の静注量による作用の変動.

4. Manetol の血餅収縮能及び血餅収縮量に及ぼす影 贸.

5. Manetol の血液凝固時間に及注す影暗.

6. Manetol の組織夜添加正常血嶈に対する作刃.

7. 湿紙 Chromatography.

附 Amino 酸油出液の正常血將飞対する作用. 研究方法及ひ研究材料

我々の従前の研究や臨床夷験からも，又，諸家の報告 からも，Manetol の出血時間に対する影暨は，大体に 扣いて出血時間を短縮するものである。一方血液の凝固 时間といらものは，多数の㠜固因子の協同作用に基づく むので，一，二の因子の不全があつても，他の多くの因 子にカバーされて，実際の凝固時間の変動はなかなか発 現してこない，従つて凝固因子には不全のものがあつて， これに Manetol を与えても Dr. W. Boll や山田等が
報告したように，凝固時間には特別な変動を起さない， 与えても，与えなくとも正常の凝固時間を示すからであ る. 従つて凝固時問が延長するのは，いくつかの擬固因 子が相当高度の不全を有する場合である，この事契を念 頭に置いて，我々は上述のような臨床並びに動物奏験を 行なつて見た．実験には体重 $54 \mathrm{~kg} \sim 62 \mathrm{~kg}$ 迄の正常人 血將と体重 $2.2 \mathrm{~kg} \sim 2.5 \mathrm{~kg}$ 家鬼血獎を用いた。

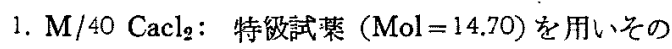
$1.47 \mathrm{~g}$ を蒸溜水 $400 \mathrm{ml}$ に溶解する.

2. 血墏：血液 9 容に $3.8 \%$ クエン酸ソーダ1容の櫘に

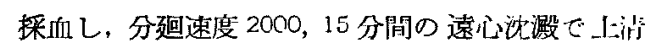
を分離する。

3. $\mathrm{Ca}$ 再加凝固時間：加藤法で測定.

4. 凝向時間測定： Lee and White 泣で测定.

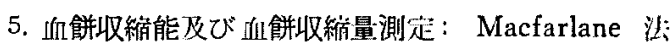
で測定.

6. $\mathrm{pH}$ 測定：がラス電極 $\mathrm{pH}$ 計を使用した.

7. 㴗紙 Chromatography：嫦法による.

8. 濾紙：東洋諰紙 No. 52

9. 組織液：家束腹壁の皮下に直径 $6 \mathrm{~mm}$ 長さ $3 \mathrm{~cm}$ の有孔ビニール管を無菌的に掼入し，1週間後，そ の管内に溜つた組織液を $0.1 \mathrm{cc}$ 使用した。

\section{研 究 成}

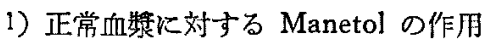

表1は，正常人の血漿に対する Manetol の作用を， $\mathrm{Ca}$ 再加凝固時間で検討したものである. 即ち $\mathrm{M} / 40$ $\mathrm{Cacl}_{2}$ 0.1ccを，3.8\%クエン酸ソーダ加採取血漿 0.1 cc に加之，37으 恒温構内で振りながら，液中に白色の Fibrin 膜を生ずる迄の時間を測定し，これを $\mathrm{Ca}$ 再加 凝固時間とする加藤法に従つて測定した成績である. 35 例の正常人血鋉で測定した成績の算術平均值を示すと表 1 の通りである.2'29" は対照として, ( $\mathrm{Cacl}_{2}+$ 血策) に

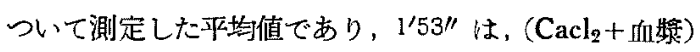
に更に Manetol $0.01 \mathrm{cc}$ 加えて測定した値の算術平

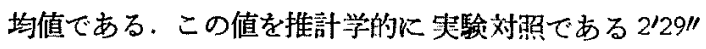


表 1

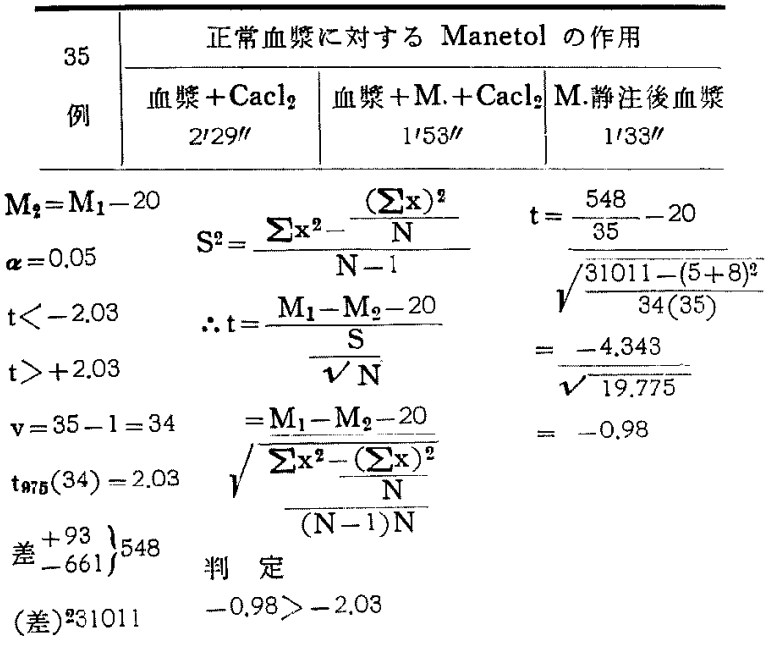

と比較すると，危険率 $5 \%$ で，表 1 の語算式示す上5

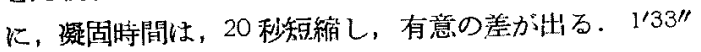

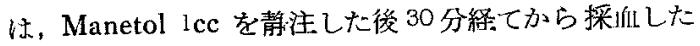

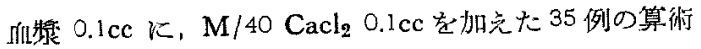

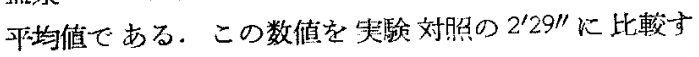
ると，推部学上有意に凝固時間は短維している。即ら Manetol は直授的嶈に作用させても, 㕛は静注しても, いずれにしても血液の㠜固を促准する作朋があり、殊に 静注の場合は有効であつた。

2) 正常血奬に対する Manetol の澧度による作用の 変動

表 2 は，正常人血獎 17 例. 家象血繁 10 例に対して，

表 2 正常血漿の Manetol 濃度差に対する $\mathrm{Ca}$ 再加凝固時間の桨化

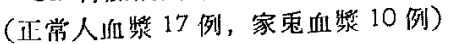

\begin{tabular}{|c|c|c|c|}
\hline \multirow[b]{2}{*}{ Manetolの泟度\% } & \multicolumn{3}{|c|}{ 平均 $\mathrm{Ca}$ 再加凝固時䦓 } \\
\hline & 距常人血獎 & 家 & 雪 Ifil \\
\hline 100 & $2^{\prime} 21^{\prime \prime}$ & & $1^{\prime} 53^{\prime \prime}$ \\
\hline 70 & $2^{\prime} 15^{\prime \prime}$ & & $1^{\prime} 33^{\prime \prime}$ \\
\hline 50 & $2^{\prime} 09^{\prime \prime}$ & & $1^{\prime} 28^{\prime \prime}$ \\
\hline 20 & $1 / 51^{\prime \prime}$ & & $1 / 17 "$ \\
\hline 10 & $1 / 55^{\prime \prime}$ & & $1 / 19 \prime \prime$ \\
\hline 5 & $1^{\prime} 57 \prime \prime$ & & $1^{\prime} 26 "$ \\
\hline 2 & $1^{\prime} 58^{\prime \prime}$ & & $I^{\prime} 23^{\prime \prime}$ \\
\hline 1 & $2^{\prime} 06^{\prime \prime}$ & & $11^{\prime \prime \prime}$ \\
\hline 食 水 & $2^{\prime} 39 \prime \prime$ & & $1^{\prime} 57 \prime \prime$ \\
\hline
\end{tabular}

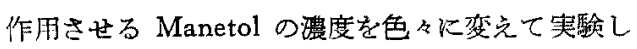
た成續を示したるのである．表のよらに Manetol の原液の濃度を100 と乙，これを順次に稀釈して， $70 \%, 50 \%, 20 \%, 10 \%, 5 \%, 2 \%$,及び $1 \%$ までにしたこの各種の澧度の Manetol を $0.1 \mathrm{cc}$ とり,こ狆に血獎 $0.1 \mathrm{cc}$ と $\mathrm{M} / 40 \mathrm{Cacl}_{2} 0.1 \mathrm{cc}$ を加 えて, $\mathrm{Ca}$ 再加凝固時間の変化を測定し, 夫々の朢 度の㠜固時間の算術平均值を出して見た，Manetol の代りに生理的食塩水を加点たものを対照として， これと比較すると，いずれの濃度の物でも推計学的 に有意に㠜固時間が短縮している。殊に與味のある 事は, Manetol を20〜10\%の清度, 即ち Manetol 原液を 10〜20倍に稀釈した濃度のものが最も強く 凝固時閏短縮した，この濃度は，後述する Paper chromatography により Amino 酸分劃を抽出し， その抽出液で㠜固時間を調べるのに丁度必要な濃度とな つたのである.

3) Manetol の静注量による作用の変㗢

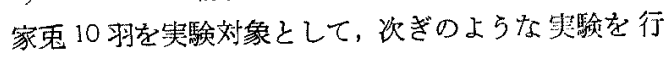
なつた。同一家象に, Manetol を $0.2 \mathrm{cc}, 0.4 \mathrm{cc}, 0.6 \mathrm{cc}$, $0.8 \mathrm{cc}$, 及び $1 \mathrm{cc} の 5$ 段階に別けて耳静脈より静注した。 注射後 30 分経過した特に採向し，その的漿 $0.1 \mathrm{cc}$ の Ca 再加凝固時間を既述の方法で測定し，10羽の夫々の時開 の算術平均値を出した。これが表了に示したものです る. 各濃度の Manetol の静注間滆は，1週閒とした。

表 3 Manetol 静注量量的差による Ca 再加 凝固時間の変化

\begin{tabular}{|c|c|c|c|c|c|c|}
\hline $\begin{array}{c}\text { Manetol } \\
\text { 静注量 cc }\end{array}$ & Occ & $0.2 \mathrm{cc}$ & $0.4 \mathrm{cc}$ & $0.6 \mathrm{cc}$ & $0.8 \mathrm{cc}$ & $1.0 \mathrm{cc}$ \\
\hline $\begin{array}{l}\text { 平均 } \mathrm{Ca} \text { 再 } \\
\text { 抓凝固㭙閒 }\end{array}$ & $l^{\prime} 55^{\prime \prime}$ & $1 / 21^{\prime \prime}$ & $1^{\prime} 29 \prime \prime$ & $1 / 37^{\prime \prime}$ & $2^{\prime} 01^{\prime \prime}$ & $2^{\prime} \mathrm{O} 9 \prime \prime$ \\
\hline
\end{tabular}

(家龟 10 羽)

なお实駼対昭として, Manetol を静注しない且獎につ いて, 同様に $\mathrm{Ca}$ 再加凝固時間の 测定を行い、これを 基潐として夫々の測定値を比較検討した，表ろで判るよ うに，家象の実験で最も $\mathrm{Ca}$ 再加凝固時間の短維を示 すのは，实驗対照の静注しない回獎のそれに比較して， Manetol 0.2cc を静注した場命である.0.4cc 及び0.6cc を静注した場合がこれに続いて凝固時間が短縮するが， $0.8 \mathrm{ec}$ 及び1 cc の静注では，逆に罗駼対照の 1/55"より

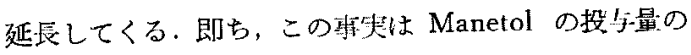


闍題に關尰していて，過量の投与では，凝血に対しむし ろ効果的でない丳を示崚している。

4) Manetol の血餅収猟能及び血餅収縮量に及ぼす影 然

表4は，家鬼10羽を用いて钼察した。.Mactarlane 法

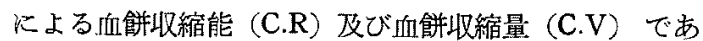
る.表中の (1) は, Manetol 0.6cc 静注後 30 分して 搡血したものを，同一動物の注射前の血液の (C.R) 及び（C.V) に此較したものである．表中の（2）は，

表 4 Ifll 餅収箘能 (C.R.) 及び抽解量 (C.V.) (Macfarlane)

(1) Manetol $0.6 \mathrm{cc}$ 游注の暘会

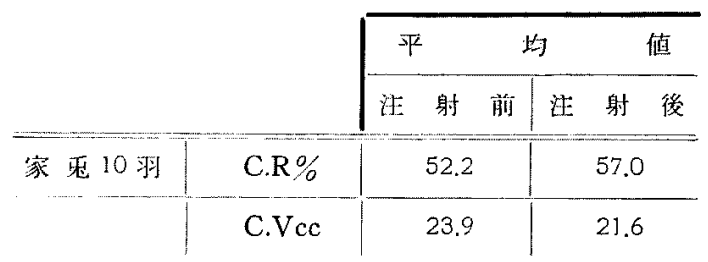

(2) Manetol $0.2 \mathrm{cc}$ 静注の場合

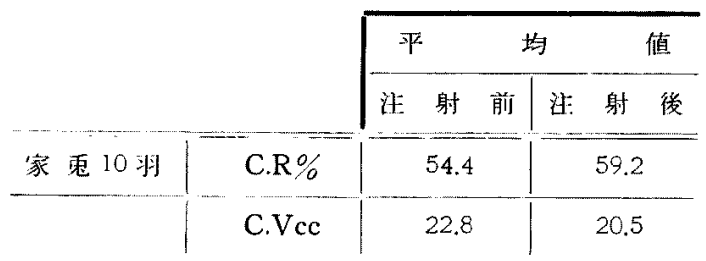

Manetol 0.2cc を静注した皿液で，同様に実駼推察した 成績である。静注した Manetol の量は，0.2ccでも

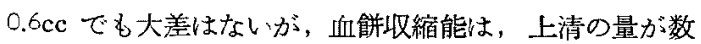
字で出ているたけ，下の血餅量が収縮している事にな

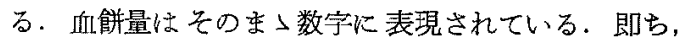
Manetol を静注すると，血餅の収緶が強くなり，血餅 量は徒つて対照より小さくなつてくる．血餅がより強く 収䈹する事がわかる。しかも，大差はないが， $0.2 \mathrm{cc}$ を 静注した場台の方が効果が強く現れているようである.

5) Manetol の伅烝疑固時間に及ぼす影響.

表5は，Manetol を家鬼に静注して 30 分後に採取し た血液の㠜固时間を, Lee and White 法によつて10羽 の家鬼について測定した值の平均值である. 前項の煬合 々同様に $0.2 \mathrm{cc}$ 及び $0.6 \mathrm{cc}$ を静注し，これを Manetol を静注しない特の平坞值と此跤唡討したるのである。そ の成績は，明らかに Manetol の静注で㠜固時間の短縮 がみられるが，0.2cc 及び $0.6 \mathrm{cc}$ の静注例の閐の差異住 大洼ないよらである。
表 5 血液凝固時閒 (Lee and White 法)

1) Manetol $0.6 \mathrm{cc}$ 静注の場合 家秉 10 羽

\begin{tabular}{|c|c|c|c|c|}
\hline & & 射 前 & 注 & 射 \\
\hline 平坞凝固㭙間 & & $6^{\prime} 01^{\prime \prime}$ & & $5^{\prime} 26^{\prime \prime}$ \\
\hline
\end{tabular}

2) Manetol 0.2cc 静注の場合 家秋 10 羽

\begin{tabular}{|c|c|c|c|c|c|}
\hline & 注 & 前 & 注 & 射 & 後 \\
\hline 可的凝固封間 & & $5 \prime 57 \prime \prime$ & & $5^{\prime} 08$ & \\
\hline
\end{tabular}

6) Manetol の組織液添加正常追槳に刘する作用 奏地臨床に和いて，手術の際に，前もつて Manetol を静注して扰くと，あるいは，局所に注射して括くと，

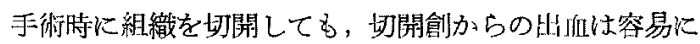
凝们してとまり易い，遠隔の部位で静注したのに，何故 北つた場所で㠜血し易くなるか，これを考光てみた，先 つ切つた場所で出血した血液は，切られた組織の組織液 と第一に接触する事になる。そこで丰験的に，家鬼腹壁 の皮下に直径 $6 \mathrm{~mm}$ の有孔ビニール管を無菌的に挿入し て，その管内に組織液を貯溜された。これを $0.1 \mathrm{cc}$ 宛使 用して表6のよらに，50\%及び20\%にらすめた Manetol

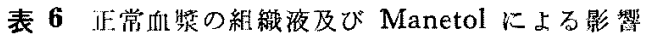
家鬼掹獎 8 例

\begin{tabular}{|c|c|c|c|c|}
\hline & $\begin{array}{l}\text { 血繁+生 } \\
\text { 食水 }\end{array}$ & 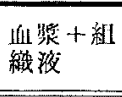 & $\mid \begin{array}{l}\text { lin } \\
\text { 液 }+50 \% \\
\text { Manetol } \\
\text { Manet }\end{array}$ & 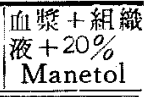 \\
\hline $\begin{array}{l}\text { 平均 } \mathrm{Ca} \\
\text { 再加凝 } \\
\text { 固㭙閻 }\end{array}$ & $1^{\prime} 15^{\prime \prime}$ & $1 / 04^{\prime \prime}$ & $55 \prime \prime$ & $48 \prime \prime$ \\
\hline
\end{tabular}

液の $0.1 \mathrm{cc}$ を家鬼血獎飞加えて，Ca 再加瀑固時間を測 定した。対照として，a）血棩に生理的食塩水を加えた もの，及び b）血齿飞組織液を加えたもの〉，夫々の Ca 再加凝固時閫を測定，比較して見た。使用家兔は 8 羽である，即ち，実験対照に比輍すると，組織液を加克 る事により，表6に示すように Manetol 加血辈の凝 血作用は，著しく增強される，即ち，局所の組織液が Manetol の局所止血効果を增強しているもの之考觉ら れる (局所組織 Thromboplastinogen の活性化). 実地 臨床的に Manetol 液を皮下や筫肉に，局所麻酶液と共 に使用しても凝血作用が頙著で，出伅に対して有奻であ る訳である。

7)濾紙 Chromatography

附. Amino 酸妯出液の正常血獎に対す当作网 表7は，独乙 Leverkusen の Bayer 本社で Paper 
表 7 Paper Chromalograph にて分碓せる物質 フルキ゚ニン

$$
\text { セデン }
$$

○グリココール

グルタミン酸

○ノルバリン

トレオニン

フエニールアラニン

アラーン

プロリン

チロジン

○チスティン

メ车ニン

ハリン

chromatography で, Manetol 液を分離した物筫（A. mino 酸) の名称である。O印は，我々が当教室で同じ く Manetol 液を Paper chromatography で分離した 結果，認める事ができなかつた物質である．他の○印以 外の Amino 酸類は我々の分類したものと一致してい る.

我々は，笑䮖的に Manetol 2cc を Chromatography 用濾紙 15 枚に漫し，80 重量\% Phenol を溶媒として Manetol 液を分離した，しかして原点より滲透㓩線を でを便宜上3つの分劃に分けて見た. 先つ, 原点より上 1/3を分劃I, 中程1/3を分劃2. その上 $1 / 3$ を分劃 3 と

表 8 正常盘獎のアミ，酸抽出液による作用

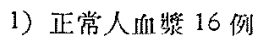

\begin{tabular}{|c|c|c|c|c|}
\hline & $\begin{array}{l}\text { 生食水 }+ \\
\text { 血獎 }\end{array}$ & $\begin{array}{l}\text { 分剽 } 1+ \\
\text { 血繁 }\end{array}$ & 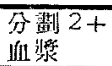 & $\begin{array}{l}\text { 分䟧 } 3+ \\
\text { 血獎 }\end{array}$ \\
\hline $\begin{array}{l}\text { 平均 } \mathrm{Ca} \\
\text { 邽加凝 } \\
\text { 国時間 }\end{array}$ & 1 '54" & $1 / 52 \prime \prime$ & $1^{\prime} 42^{\prime \prime}$ & $1 / 27^{\prime \prime}$ \\
\hline
\end{tabular}

2) 正常人洏俆

\begin{tabular}{|c|c|c|c|c|c|c|c|}
\hline & $\begin{array}{l}\text { 生食 } \\
\text { 水十 } \\
\text { 血獎 }\end{array}$ & $\begin{array}{l}\text { 分劃 } \\
1+ \\
\text { 血獎 }\end{array}$ & $\begin{array}{l}\text { 分割 } \\
2+ \\
\text { 血獎 }\end{array}$ & 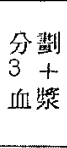 & $\begin{array}{c}\text { 分副 } \\
\left(\frac{1+2}{2}\right) \\
+ \\
\text { 血獎 }\end{array}$ & $\begin{array}{c}\text { 分劏 } \\
\left(\frac{2+3}{2}\right) \\
+ \\
\text { 近獎 }\end{array}$ & $\left.\begin{array}{c}\text { 分副 } \\
\left(\frac{3+-1}{2}\right) \\
+ \\
\text { 血漿 }\end{array}\right)$ \\
\hline 平均 $\mathrm{Ca}$ & & & & & & & \\
\hline $\begin{array}{l}\text { 再加 凝 } \\
\text { 固時間 }\end{array}$ & $1 / 08 / \prime$ & $1^{\prime} 09^{\prime \prime}$ & $52^{\prime \prime}$ & $53 \prime \prime$ & $55 \prime \prime$ & $50^{\prime \prime}$ & $1^{\prime} 09 / 1$ \\
\hline
\end{tabular}

3) 家東 8 羽

分割了より無機金属イオン分割のみ取り出し，抽出 液上り行つた $\mathrm{Ca}$ 再加凝固时間。

\begin{tabular}{|c|c|c|}
\hline & 生食水十血獎 & $\begin{array}{l}\text { 焎㙨金屈イオン } \\
\text { 抽出液十监浆 }\end{array}$ \\
\hline $\begin{array}{c}\text { 平 均 } \mathrm{Ca} \text { 再 妿 } \\
\text { 凝 固 時 }\end{array}$ & $1^{\prime} 15^{\prime \prime}$ & $1 / 14 \prime \prime$ \\
\hline
\end{tabular}

したこの各々の分劃を $\mathrm{pH} 56$ の注射用蒸溜水で，夫

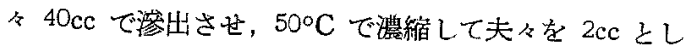

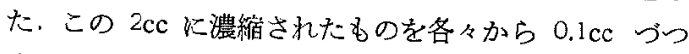
取り，上述した通りの方法で $\mathrm{Ca}$ 再加凝固時間を测定 し, 別に対照として $0.1 \mathrm{cc}$ の生理的食塩水を使用して, 同様に Ca 再加凝固時開を測定した，僛定に做用した

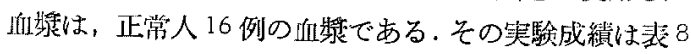
に示した通りである. 装8の1)では，分副 2 及び3に 凝固時間の短縮を諗める. 表8の2)であ同椂に分劃 2

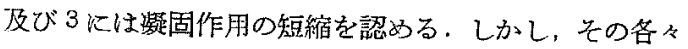
の分劃の相互の間には，いかなる関係があるかを知るた めに，分劃 1 及び 2 を等量に混合したるのを゙ $0.1 \mathrm{cc}$, 同 橡に $(2+3),(3+1)$ の分劃も $0.1 \mathrm{cc}$-゙つをとり，同 様の实跧を行なつた所 $(2+3)$ の分劃で最も強く凝固作 用を認るた。表8の3)は，Phenol を溶媒とした展開 濾紙上で，最上部の透前線の的 $1 \mathrm{~cm}$ 位の幅の間に， Fe イオンを主とする金属イオンが集つている事が認め られたので，こ〉を $1.5 \mathrm{~cm}$ 幅に切つて，その内谷奖抽 出した。この抽出液を濃縮したものについて同じょうに

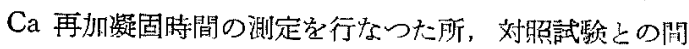
に㱠んど差をみとめられなからた。結局，Manetol 小

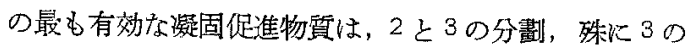
分劃中にあるらしい事が明らかとなつた，この 2 及び3

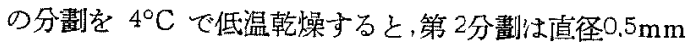
位の立万晶形結晶として，第 3 分劃俚直径 $1.5 \mathrm{~mm}$ の科 力晶形絬晶として得られる。な梅第 2 及び第3分劃中 に展開された头々のアミノ酸は，第 2 分劃中には，Lysine, Arginine, Threonine, Histidine, Alanine, 第 3 分劃中には Valine, Leucine, Proline, Phenylalanine, Methionine 等を含有している。但し，Manetol 液の血 液凝固作用がアミノ酸以外の物質兆当然含まれている だちといら事は，栲虑しなければならない，殊にこの 第3 分劃中には，Adenosinphosphate る混入するため に、Amino 酸だけが有効成分だとは確信はできない。

\section{総括及 $ひ$ 考按}

止血成の効果を判定する事は，臨床上の様々な条件が 入つてくるし，㕛個々の使用症例によつても相当遠うの で，非常に困難な場合が多い，我々は上述の上らな実駼 成績から Manetol の止血作用を考接すると, 各奏験と も主腿点は Manetol の凝血作用に焦点が絞られてい る、これは緒窉でも述べたよらに，Manetol に止血効 果のある事は，多くの臨床医家の報告にある通りで，一 般にる認められている。だとの実験成績として知られ 
ている出血時間の短縮については，田村，門脇，富垣， 大森，福田等をはじめ多くの研究者の報告が一致してい るが，㠜血時間に関しては，Dr.W. Bolle 及び山田等 の一部砸究者が，短縮を示さないと言ら報告を出してい るに過ぎない，そこで我々は牙の真偽を確かかる意䟣に おいて，凝固時間を中心として本研究を開始したのであ る. その結果は我々の実騟成續全体が示している通り， Manetol の凝固時閣を短縮する作用が，充分隹認めら れたのでする。しかをの凝国作用は，生体内において のみ起り，試臾管内反応起らないと言われていたが， 我々の突験では明らか試験管内でも反応がみられた。 この点は; 後箪の報告とは一效しない。

注目に値する実験の一つは，Manetol の濃度別によ る凝血時間の測定である.前項に示したよらに, Manetol の 20〜10\%の濃度のものを使用した時が，最もよい㠜 血効果を示していて，100\%の濃度では垁験対照として 生理的食䘏水を使用した場合と大差がないここの事夷は， 牛脳の組織性 Thromboplastine である Trostin の濃 度別の Ca 再加凝固時間の測定に和いて，1〜20\%の領 域に最も強い凝血時間の短縮を認めると云ら武井の報告 と相通ずるものがある。

Manetol 1Ample を静注した後で採取した血獎の Ca 再加凝固特間は，正常人の場合には，推計学上でも有意 の差を珰められる位短縮しているが，家惠に 1Ample 它静注した場合，逆㠜血時間の延長を起してくる。こ

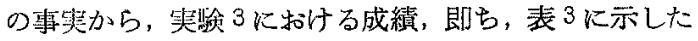
よらな投与量の問題が生じてくる. 即ち，家象に Manetol を静注した場合，0.2cc を静注した後の測定が最 も凝固时間の短維が強くあらわれ，1cc 静注した时の測 定值は逆に延長をきたしている. 笑験では Manetol を $0.2 \mathrm{cc}$ 万至 $0.6 \mathrm{cc}$ の間を投与した場合が有知であると葆 完られる・そこで再び家鬼で，Macfarlane の血餅収縮 能及び血餅叫箱量と，Lee and White 法による血液凝 固时間の湘定を，0.2cc 皮び 0.6cc 静注してから行つて 見た所，共に㠜固作用の增進が著明に認められた。この

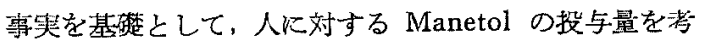
えて見ると，家鬼の総血液量を Boycott の体重の 5.4\% と見做し，正常人の血淮量を体重の7〜8\%と見做して 換算すると，正常人に対しての最も効果的な Manetol の投与量は，静注の湯合，6〜7cc であろらと推定でき る.但し、これはあくまで推論に他ならない, Manetol の投与量に関しては，大藤俚出血患者に対し，最初 $2 \mathrm{cc}$ まで竫注し，その後は，24時間以内に 7〜8cc の大量
筋注を行つた所, 所期の効果があつて, 且つ副倠用はみ

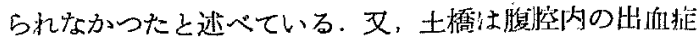
例に Manetol を使用し，2日間に11 本方筋注を行い， 止牦し難いと云われていた腹腔内出血を完全に止血せし めている、文，大森は尿路出系に際し，Manetol を优 用しているが，1Ample では効力がおとるために，1回 2Ample 宛を用い，数回連続投与して効果をあげてい る.これらの報告から考えて Manetol は詐されるなら ば，成人の斯合は，6〜7cc の大量投与をして，以後止 IfID目的を完成する迄は維持量を与える心きかとる考え られる、これはあくまでる推論ではあるが，考光られる 牙と信ずる。

実駼6及び 7 は，主に Manetol が組䅧液を混合した 場会の止伹に及淁す効果と，Paper chromatography て 分析，抽出した Amino 酸を使腃して凝血作用を観察 したものである。殊組織液については，大藤及び田村 等は登溜水で薄めた Manetol を浸したガーゼタンポン を局所にあてがつて，止血效果があつたと報告してい る. 局所組織に Manetol を注射して执いてから切開す ると出血が少ないと云う白岩の報告すある、これらの報 告から考えても, 組織液内の組榓 Thromboplastinogen が手術操作などに因つて活性化され，それ自体直接㠜血 効果を示すが，こ机更に Manetolが作用してその効力 を一畨促進させるるのと考える。しからば Manetolの 有效成分は何かというと， Manetol の主構成々分であ るAmino 酸各污の主役を演ずるるのと考光られる。併 L, Manetol 中には Amino 酸以外の物質も色々と含 串れている事は当然考慮されれるので，Amino 酸のみに 此们作朋があるとは勿論云えない，我々が咨験的に分劃 した最有效な Fraction 中の Amino 酸のいくつか

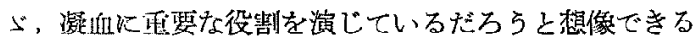
わけである。

\section{結語}

1.我々は Thromboplastin 製成の Manetol の作用 を，午の㠜固作用に焦点を絞り，璉々研究を行つた。

2. Manetol は，南接血獎に作用させても，静注して

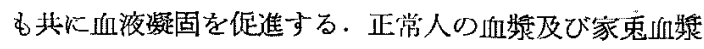
に対する最む有効な Manetol の濃度は, Ca 再加㠜固 時間を指標として観察すると，Manetol 液の 20\%〜50 \%位の稀採液である。特に 10\%〜20\%の液で最も強く 㠜固を促進する。

3. Manetol を家鬼に静注した場合， $0.2 \mathrm{cc} \sim 0.6 \mathrm{cc} を$ 静注した时が最る凝固を促進させる、就中， $0.2 \mathrm{cc}$ 投与 
の際が最高である.

4. 家鬼で最も著効を奏した投与量から換算して見る 之, 成人の場合は，6〜7cc（但し静注）の投与が，最効 果あるものと推定できる。

5. 予め Manetol を与えておいた望合の，手術時など の切開創に打ける止血作用は，その一因子として,局所の 組織液内の組織 Thromboplastinogenが切開で活性化さ れて，これが有力に凝血に関与するるのと考えられる。

6. Manetol .止血作用は，その主成分たる数種の Amino酸が主役を演ずるものではないかと想像される。

7. 各種の実戨中, Manetol の副作用は認められなか つた.

\section{参考文 献}

1) Boll, W: Dtsch. med. Wschr. 51, 2092. 稲田務他：日本臨床，Vol. 10, No. 12, 1952. 3) 田 村崒雄他：綜合臨床, Vol. 3, No. 2, 1954 . 4) 石倉 武雄他：Manetol 交献集 1. 5) 馬場正次他：文献 集 1. 6) 大森敏直他：Manetol 文献集 2.67 )

後藤修二他：耳舅咽喉科，Vol. 29, No. 6, 1957.
8) 大藤敏三他：耳率咽啹科, Vol. 29, No. 7, 1957 .

9）山田 佐：Manetol 文献集 3. 10) 土䨩秀考他: Manetol 文献集3. 11) 松村敏之：臨床皮消泌尿科， Vol. 12, No. 2, 1958 . 12) 白岩俊焳：鶃腔, 咽頭領 域の出血に関する研究（宿題報告）13）武井直人： 東京医科大学雑誌, Vol. 17, No. 4, 1959. 14) 福武 勝博，菅野浩和：血液凝固検査法.15）柴田村治： 濾紙クロマトグラフイー法の実際。16）安東洪次他： 動物実験法.

本研究に当り御援助下さつた吉富製薬株式会社ハ イエル薬品部に感謝します

(本論文の要旨は，昭和 35 年 11 月 13 日，日本耳

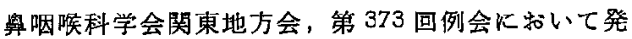
表した.)

（原稆到着 $=$ 昭和 36.7 月急載）

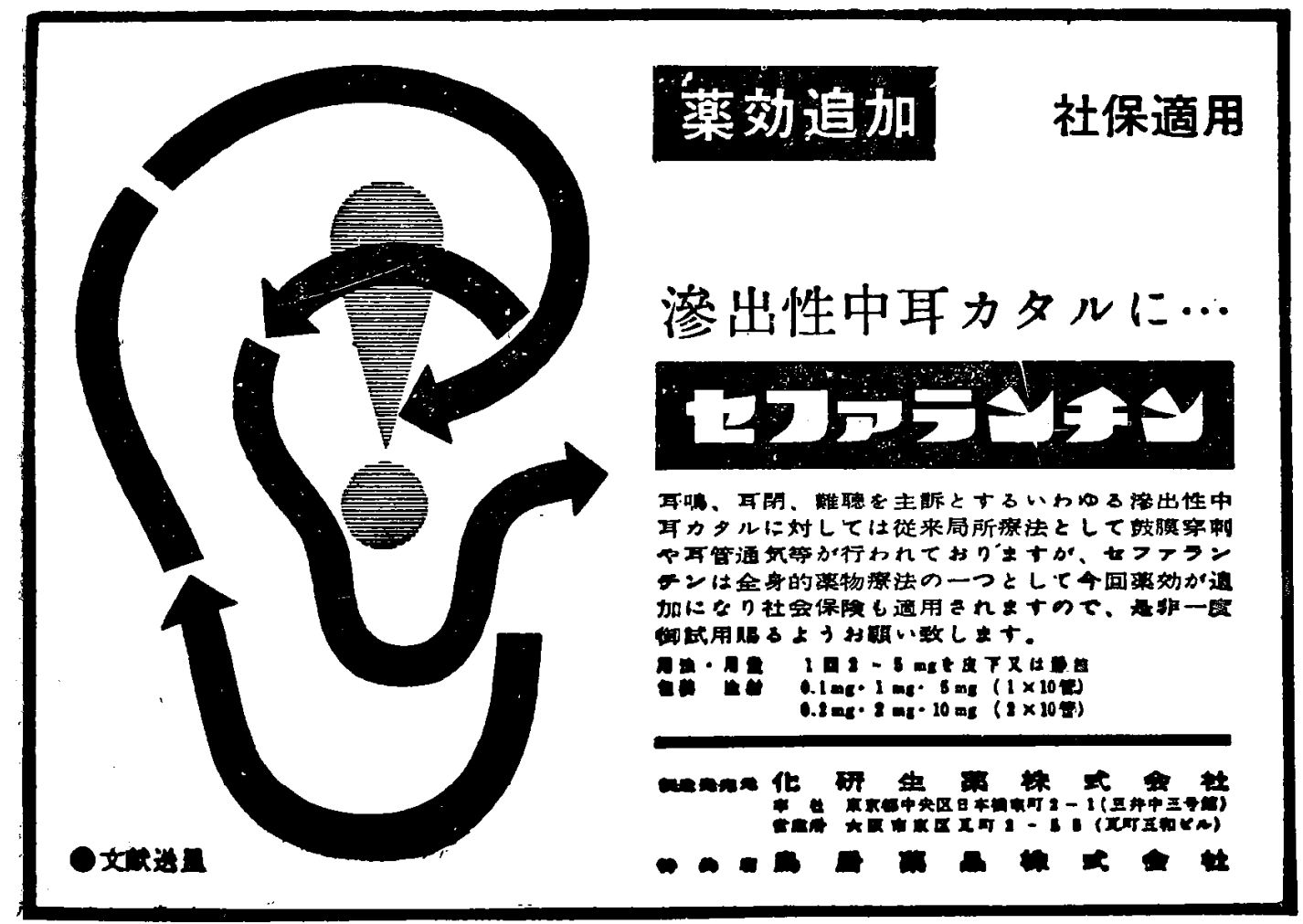

